A relação entre comunicação e educação se coloca hoje, sobretudo no Brasil e na América Latina, como um campo renovado de estudos e pesquisas, práticas e questões. No Brasil, em 1997, desenvolveu-se uma pesquisa denominada "Perfil", realizada pelo Núcleo de Comunicação e Educação (NCE-ECA/USP), com o apoio e incentivo da FAPESP, que tinha como objetivo analisar o profissional que atua na inter-relação Comunicação e Educação. A partir daí, a inter-relação Comunicação-Educação passou a ser considerada como "um novo campo de intervenção social" e recebeu definições de subáreas de atuações e estudos, ao mesmo tempo em que também passou a ser denominado de Educomunicação.

Desde então, Soares, ${ }^{1}$ pioneiro na área e coordenador desses estudos, entendeu que a inter-relação Comunicação e Educação ganhava densidade própria e se afigurava como um novo campo de intervenção social, oferecendo conseqüentemente um novo espaço de trabalho em toda a América Latina, emergindo então a figura do profissional denominado Educomunicador. A partir de então Soares passou também a nomear este campo como de Educomunicação ${ }^{2}$.

A pesquisa demonstrou que o campo tem vários trabalhos e tipo de atuações, que em dado momento se entrecruzam, por causa das preocupações com a educação e com o processo de ensino e aprendizagem e, em outros, se distanciam pela concepção de distintos processos comunicacionais. $\mathrm{O}$ resultado da pesquisa apontou para a organização do novo campo em cinco categorias de atuações, chamadas de sub-áreas da
Educomunicação: 1) educação para a comunicação, 2) mediação das tecnologias na educação, 3) gestão da comunicação nos espaços educativos, 4) da reflexão epistemológica e, posteriormente ao lançamento dos resultados da pesquisa, a quinta subárea que é a expressão comunicativa através das artes. No presente texto, sobre as referências bibliográficas comentadas da área da Comunicação e Educação indicaremos textos e livros que direta ou indiretamente estão ligadas as sub-áreas assim classificadas por Soares.

\section{Educação para a comunicação}

Essa sub-área foi constituída inicialmente por trabalhos e estudos com o objetivo de formar o receptor para leitura e análise dos meios com fortes influências da Teoria Crítica, bem como pelo projeto desenvolvido no Brasil, LCC - Leitura Crítica da Comunicação, da União Cristã Brasileira de Comunicação Social UCBC. Como os documentos a respeito não foram publicados em formato de livro, o que temos são os relatos no livro-tese "Leitura dos Meios de Comunicação"3. Apesar da leitura crítica ainda hoje ser seguida, as primeiras propostas e projetos foram duramente criticados por terem uma postura moralista. Os trabalhos publicados nessa linha de estudo são significativos para que pesquisadores da área possam ter uma idéia dos avanços, dos equívocos e das questões que ainda estão em aberto a respeito, tal como a indagação de MartínBarbero: "por que o dominado se deixa seduzir pelo dominador?"4

Com o forte avanço dos Estudos

Culturais na América Latina, a
(01) Referências bibliográficas de Soares estarão na bibliografia do artigo.

(02) O projeto da Fapesp pode ser encontrado na integra na biblioteca da ECA/USP e o texto sobre a pesquisa na coletânea: Formação do Educador: avaliação institucional, ensino e aprendizagem, v. 4/ organizadores Maria Aparecida Viggiani Bicudo e outros, São Paulo, UNESP, 1999. (seminários \& Debates).

(03) Moran, José Manuel. Leituras dos Meios de Comunicação, São

Paulo, Pancast, 1993.

(04) MARTÍN-BARBERO, Jésus.

De los medios a las mediaciones.

Ed. GG/Mexico.

MARTÍN-BARBERO, Jésus . PréTextos, Conversaciones sobre la comunicacion y sus contextos, Coleccion Ensayo

Iberoamericano, Ed. Centro Editorial Universidad del Valle, Cali - Colômbia, 1995.

\section{Eliany Salvatierra Machado é}

professora e pesquisadora da Faculdade Montessori - FAMEC, São Paulo, e Doutoranda na ECA-USP na área de Comunicação e Educação. 
(05) Gómez, Guilherme Orozco. Televisión audiências y educación, Encidopédia Latinoamericana de Sociocultura y Comunicación, Colômbia, Grupo Editorial Norma, 2001.

(06) Fischer, Rosa Maria Bueno. Televisão \& Educação: fruire pensar a TV, Belo Horizonte, Autêntica, 2001.

(07) Revista Comunicação \& Educação, publicada pelo curso de Gestão de Processos Comunicacionais, do Departamento de Comunicações e Artes da ECA-USP, 2001.

(08) Revista Novos olhares, publicada pelo Grupo de Estudos sobre práticas de Recepção e Produtos Mediáticos, da ECA-USP. (09) Figueiredo, Vera Follain de, et al, Mídia e Educação, Rio de Janeiro, Gryphus, 1999. (10) Revista USP, publicada pela Coordenadoria de Comunicação Social, Universidade de São Paulo, n. 55.

(11) Braga, José Luiz e Calazans, Maria Regina Zamith.

Comunicação e Educação: questões delicadas na interface, São Paulo, Hacker, 2001.
Educação para os Meios estuda e pensa o receptor ativo. Dentro dessa perspectiva importa estar atento aos trabalhos de Guilhermo Orozco Gómez ${ }^{5}$, que reflete sobre a audiência televisiva e as mediações, discutindo a audiência e as novas abordagens e modos de vê-la, a linguagem, a técnica e a instituição televisiva. $O$ livro aborda também a educação e o processo de ensino- aprendizagem, as palavras e as imagens, políticas educativas, conteúdos e métodos, recursos didáticos, destempos televisivos e Educomunicações.

A contribuição de Rosa Maria Bueno Fischer6 tem como objetivo analisar a relação televisão e educação, demonstrando como o tema pode ser abordado em sala de aula e como podemos discutir pontos interessantes através da experiência dos alunos, que são, segundo ela, antes de tudo, telespectadores. Para Fischer, a TV faz parte do cotidiano de educadores, pais e alunos, e isso exige da escola novas maneiras de perceber as relações entre televisão e sociedade. Nesse mesmo sentido, a revista Comunicação e Educação, da ECA-USP, também traz em seu bojo várias discussões e análises, seja quanto a relação entre educação e televisão, ou textos que abordam temas como: jornal e educação, Internet e educação ou mesmo discussões mais complexas como a epistemologia da Educomunicação ${ }^{7}$.

O tema da recepção mediática se coloca igualmente como importante nos estudos e pesquisas dentro dessa sub-área de comunicação e educação. A Revista Novos Olhares do CTRECA-USP tem sido uma fonte instigante de questões e artigos pertinentes a essa área ${ }^{8}$.

"Mídia \& Educação", da coleção Educação em Diálogo, também é uma boa fonte de consulta sobre a educação para a comunicação. No volume IV, por exemplo, a preocupação se dá com a formação do cidadão crítico em contraposição ao consumidor inocente e sugere estratégias para adaptar a escola aos novos tempos?.

\section{Mediação das tecnologias na Educação}

A sub-área da Mediação das Tecnologias na Educação, considerada por Soares como a área que compreende os procedimentos e as reflexões em torno da presença e dos múltiplos usos das tecnologias da informação nos diversos processos educativos, acaba sendo a sub-área que agrega os trabalhos e estudos com o objetivo de pensar ou elaborar propostas com meios tecnológicos que auxiliem no processo de ensinoaprendizagem. A perspectiva não é mais ensinar a ler ou interpretar os meios, ou mesmo o estudo das relações que o receptor estabelece com os mesmos, mas criar ou associar dispositivos para que os educadores, ao trabalharem com os meios de informação, facilitem ou ampliem o processo de ensinoaprendizagem. Nesse sentido, temos o projeto Educom.TV discutido no texto: "Educação a Distância como Prática Educomunicativa: Emoção e Envolvimento na Formação Continuada de Professores da Rede Pública $^{10}$, que mostra como projetos podem criar ecossistemas comunicativos, a distância, que sejam abertos e criativos em espaços educativos, favorecendo as relações dialógicas.

Outro texto que segue essa mesma linha é a publicação "Comunicação e educação: questões delicadas na interface", que, segundo os autores, tem como um dos objetivos discutir a superação da dualidade, considerada simplificadora, entre as interações educacionais facea-face - presencial e os procedimentos mediáticos - a distância. ${ }^{11}$

Essa sub-área, apesar de ter vários textos e livros publicados, é freqüentemente confundida também com o que vem sendo chamada de Novas Tecnologias na Educação. Nessa perspectiva específica os textos publicados, mesmo que sejam análises do ponto de vista tecnológico e não educomunicacional, conseguem subsidiar as discussões e reflexões, como por exemplo "Novas Tecnologias da Educação e Sociedade na Era 
da informação", que é uma tentativa de "estabelecer um diálogo entre as diversas problematizações que nosso tempo infere na percepção do homem e da técnica"12.

\section{Gestão da Comunicação nos Espaços Educativos}

Essa terceira sub-área compreende toda a ação voltada para o planejamento, execução e avaliação de planos, programas e projetos de intervenção social no espaço da interrelação comunicação/cultura/ educação, criando ecossistemas comunicacionais. Consiste em trabalhos que discorrem sobre projetos e ações implantados e implementados em espaços da educação formal ou não-formal, como é o caso do projeto Educom.Rádio São Paulo ${ }^{13}$.

Uma outra publicação a ser consultada que aponta reflexões nesta sub-área é "Mídia \& Educação: perspectivas para a qualidade da informação", resultado do Fórum homônimo, realizado em São Paulo, no ano de 1999, em uma tentativa de apresentar projetos com características educomunicativas ${ }^{14}$. Outro material que não é específico de gestão mas apresenta vários exemplos é a publicação da TV Escola fornecida pelo Ministério da Educação em formato impresso e on-line: "TV na Escola os desafios de hoje"15.

A revista Acesso, publicada pela Fundação para o Desenvolvimento da Educação $^{16}$ e organizada pelo equipe da GIP - Gerencial de Tecnologia Educacional, apresenta projetos em desenvolvimento e reflexões sobre a área. Artigos como: "A informática nas escolas públicas”, “Gestão escolar: como transformar a rotina em desafio?", ressaltam questões e propostas na área do acesso e capacitação e apresentam análises, problemas e soluções".

\section{Reflexão Epistemológica}

Essa área, segundo Soares, envolve estudos da comunicação e educação como fenômeno cultural emergente no campo acadêmico. A coletânea de Carlos Eduardo Valderrama $\mathrm{H}^{17}$, publicada na Colômbia, envolve textos a respeito de Ismar de Oliveira Soares, Jorge A. Hurgo, William Fernando Torres, Aníbal Ford, Guilhermo Orozco Gomes, Humberto J. Cubides C, Joan Ferres i Prats, Jesús Martín-Barbero, entre outros. O livro indica dois pontos de vista: a de Jorge Hurgo e a de Ismar Soares. O primeiro considera o espaço da interação entre a comunicação e a educação como uma confluência de diversas perspectivas teóricas, de práticas sociais e profissionais com interesses distintos e que como campo pode ser atravessado a partir de três tipos de relações: institucionais educativas e horizontes culturais, educação e meios de comunicação, além de educação e novas tecnologias. Ainda na mesma direção William Fernando Torres, assume como um campo estratégico do conhecimento que possibilita construir um saber experimental e transdisciplinar com a finalidade de propor políticas para a construção do sujeito, inscrito em sociedades periféricas que tendem à globalização econômica. Já Soares considera que a inter-relação Comunicação e Educação consiste em um novo campo de conhecimento e esse campo, inaugurado a partir de um novo paradigma, que sustenta a hipótese de um campo de conhecimentos com autonomia que se encontra em processo de consolidação. Soares, conforme Valderrama considera que o campo é de natureza relacionai e estruturado como processo mediático transdisciplinar e interdiscursivo, e se materializa em quatro sub-áreas de intervenção social. Apóia-se também na afirmação de que já existe uma comunidade com seus perfis claramente definidos.

Em "Comunicacíon/Educación: âmbitos, práticas y perspectivas"18, Huergo coloca claramente a necessidade de publicações de estudos mais aprofundados sobre a interrelação Comunicação e Educação. Outra obra fụndamental e de referência para a sub-área da reflexão
(12) Silva, Mozart Linhares da (org). Novas tecnologias educação e sociedade na era da informação, Belo Horizonte, Autentica, 2001.

(13) wuw.educomradio.com.br (14) Mídia e Educação: perspectivas para a qualidade da informação, Brasília, 2000.

(15) TV na Escola os desafios de hoje, publicado pela Seed? MEC e UniRede, Brasília, 2001.

(16) Acesso, revista de Educação e Informação, publicação da Fundação para o Desenvolvimento da Educação Gerencia de Tecnologia Educacional, órgão vinculado à Secretaria de Estado de Educação - www. educacao.sp.gov.br (17) Valderrama $H$, Carlos Eduardo, et alli. ComunicaciónEducación: corrdenadas, abordajes y travesías, Santafé de Bogotá: Siglo Del Hombre

Editores Fundación Universidad Central, departamento de Investigaciones, DIUC, 2000. (18) Huergo, Jorge A. Comunicación-Educación: âmbitos, práticas y perspectivas, La Palta, Argentina, Ediciones de Periodismo y Comunicación, 1996. 
epistemológica é "La educación desde la Comunicación", um trabalho de Jesus Martín-Barbero mais ampliado que o texto com o mesmo título publicado em 1997 pela revista Nômade da Colômbia ${ }^{19}$.

A Expressão Comunicativa Através das Artes também compõe o campo da Educom. buscando o desenvolvimento da capacidade criadora e expressiva, e tem como objetivo ampliar a capacidade de expressão do jovem. Essa ampliação da capacidade expressiva dentro da perspectiva comunicacional, contudo, espera que o jovem consiga expressar seus desejos, angústias, visões de mundo e mais especificamente da comunidade em que pertence. Nesse sentido, o projeto Educom Rádio São Paulo representa um expressivo trabalho, com produções radiofônicas publicadas no site ${ }^{20}$. Há ainda os trabalhos da Associação Imagem Comunitária através do projeto "Rede Jovem de Cidadania”21.

\section{Bibliografia do Artigo}

(19) Martín-Barbero, Jesús. La educación desde la comunicación, Buenos Aires, Grupo editorial Norma, no prelo.

(20) www.educomrádio.com.br. (21) www.aic.org.brou www.redejovembh.org.br
BACCEGA, Maria Aparecida. Televisão e educação: a escola e o livro. Revista Comunicação \& Educação. Gestão de Processos Comunicacionais, CCA- ECA-USP

BICUDO, Maria Aparecida et alli (org). Formação do Educador: avaliação institucional, ensino e aprendizagem. São Paulo, UNESP, 1999.

BRAGA, José Luiz e CALAZANS, Maria Regina Zamith. Comunicação e Educação: questões delicadas na interface. São Paulo, Hacker, 2001.

FIQUEIREDO, Vera Follain de. et al, Mídia e Educação. Rio de Janeiro, Gryphus, 1999.

FISCHER, Rosa Maria Bueno. Televisão \& Educação: fruir e pensar a TV. Belo Horizonte, Autêntica, 2001.

HUERGO, Jorge A. Comunicación-Educación: âmbitos, práticas y perspectivas. La Palta, Argentina, Ediciones de Periodismo y Comunicación, 1996.

MACHADO, Arlindo. Bibliografia Comentada: Pode-se amar a televisão? Revista Novos Olhares, no 05, 2000.

MARTÍN-BARBERO, Jésus. De los medios a las mediaciones. Ed. GG/ Mexico.

. La educación desde la comunicación. Buenos

Aires, Grupo editorial Norma, no prelo.

. Pré-Textos, Conversaciones sobre la

comunicacion y sus contextos. Coleccion Ensayo Iberoamericano, Ed. Centro Editorial Universidad del Valle, Cali - Colômbia, 1995.

MORAN, José Manuel. Leituras dos Meios de Comunicação. São Paulo, Pancast, 1993. 
OROZCO GÓMEZ, Guilhermo. Televisión audiências y educación.

Enciclopédia Latinoamericana de Sociocultura y Comunicación, Colômbia, Grupo Editorial Norma, 2001.

SILVA, Mozart Linhares da (org). Novas tecnologias - educação e sociedade na era da informação. Belo Horizonte, Autentica, 2001.

SOARES, Ismar de Oliveira. Caminhos da Educomunicação na América

Latina e nos Estados Unidos. Agenda do educom.rádio num. 1, São Paulo, 9 a 16 set. 2003.

Comunicação/Educação: a emergência de um novo campo e o perfil de seus profissionais. Contato, ano 1 num.2, Brasília, jan/março 1999

Educomunicação: as perspectivas do reconhecimento de um novo campo de intervenção social: o caso dos Estados Unidos. Eccos Revista Científica Uninove (v.2 n.2), dez 2000b

Lei de Diretrizes e Bases e a Comunicação

no sistema de ensino. Revista Comunicação \& Educação (8), São Paulo, 1997.

Sociedade da informação ou da comunicação.

São Paulo: Cidade Nova, 1997

Professores e meios de comunicação:

desafios, estereótipos. Revista Comunicação \& Educação (10), São Paulo, 1997.

Educação a Distância como Prática

Educomunicativa: Emoção e Envolvimento na Formação Continuada de Professores da Rede Pública. Revista USP, no 55, 2002.

SOUSA, Mauro Wilton de. Práticas de Recepção Mediática como Prática de Pertencimento Público. Revista Novos Olhares, no 3, 1999.

VALDERRAMAH, Carlos Eduardo, et al. Comunicación-Educación: corrdenadas, abordajes y travesías. Santafé de Bogotá: Siglo Del Hombre Editores Fundación Universidad Central, departamento de Investigaciones, DIUC, 2000. 